\title{
Effectiveness of group guidance using Expressive Arts Therapy in improving self management of sexual harassment among vocational high school students in city of Pinang
}

\author{
Rismaniar ${ }^{1}$, Firman ${ }^{1}$ \\ ${ }^{1}$ Universitas Negeri Padang \\ ${ }^{*}$ Corresponding author, e-mail: rismaniar33@gmail.com
}

\begin{abstract}
The case of sexual harassment are more and more extends, spread, and found a lot in several areas, the city, even among all these villages not only the community but also in the world of education in indonesia. Sexual harassment case it is becoming even diverse and no longer eat his victims who are in the age range of adult, but those who are in the age range of teenagers even children very much a victim or an offender sexual harassment. Sexual harassment that occured in schools happened because of incompetence students in regulating and manage himself with good. One of the efforts was to enhance the capacity of students in regulating and manage himself in do sexual harassment is to hold guidance services use the art of expressive of group. The sample as many as 13 students for the experiments on class, $X, X I$ and 13, students to the control group the sample used are proportionate stratified random sampling. Statistical analysis of data used in this research are nonparametrik statistics. Instruments gather data using the model scale likert, data analyzed using wilcoxon signed ranks kolmogorov-smirnov test and with the help of two independent sampels spss 20. Version. The findings of this study are: 1) there is a significant differences self management group experiment before and after given guidance services group use an expressive art therapy, 2) there is a significant differences self management control group before and after the guidance given services without special treatment, 3) there is a differences self management group experiment given guidance services group use an expressive art therapy to the control group given guidance services group about self management without special treatment, this was apparent from the score average postest group experiment rise higher than the average posttest score control group.
\end{abstract}

Keywords: Sexual harassment, self management, expressive arts therapy, group counseling

How to Cite: Rismaniar, R., \& Firman, F. (2021). Effectiveness of group guidance using Expressive Arts Therapy in improving self management of sexual harassment among vocational high school students in city of Pinang. International Journal of Applied Counseling and Social Sciences, 2 (2): pp. 186-193, DOI: $\underline{\text { https://doi.org/10.24036/005458ijaccs }}$ 


\section{Introduction}

Nowadays cases of sexual harassment is a social fact that still happens a lot. This is evidenced by the widespread reporting of cases of sexual harassment and obscenity on television screens, social media or those that are in direct contact with people's lives. Cases of sexual harassment are increasingly mushrooming, spreading, and can be found in several areas, cities, and even villages in Indonesia. Technological developments are growing rapidly, making it easier for people to access information via the internet. Information circulating on the internet is not only information that is positive and provides knowledge but also information that is negative and leads to things that are not good, for example news about pornographic images. This information is so easily accessed by anyone, both adults, teenagers and even children, through various media. So that any teenagers who vent their sexual desires and desires to friends and the surrounding environment (Firman \& Syahniar, 2018).

Komnas Perempuan data shows that in 2014, there were 4,475 cases of sexual harassment, in 2015 there were 6,499 cases and in 2016 there were 5,785 cases, in 2017 there were 2,979 cases of sexual harassment, in 2018 the number of sexual harassment cases actually reached 5,280 cases (Komnas Perempuan, 2012). 2019). In 2016, Lentera Sintas Indonesia found that from a survey with 25,213 male and female respondents, it was found that $58 \%$ of respondents reported having experienced verbal sexual harassment, $25 \%$ had experienced sexual harassment in the form of unwanted physical actions such as being touched, massaged, squeezed, hugged. or being kissed and over $20 \%$ reported having been coerced into viewing or viewing pornographic content, viewing someone's genitals or witnessing sexual activity. As many as 6\% of respondents admitted to having experienced rape (Rusyidi et al., 2019).

The high number of sexual abuse in North Sumatra in the period January to July 2019, as many as 526 children became victims of sexual abuse. This figure emerges from 458 cases that are now in the spotlight for the North Sumatra Women's Empowerment and Child Protection Service (PPPA). The head of the North Sumatra PPPA Service said that sexual abuse of children was the most common case in North Sumatra (Andriansyah, 2019).

Widyastuti (2009), adolescents will go through a high-risk developmental stage to be involved with many social problems starting at the age of 14 years. Among the social problems that are often carried out by teenagers are being involved in sexual behavior, especially sexual behavior outside of marriage. This is supported by the research of Firman, Syahniar (2018), 27.37\%, high school teenagers commit sexual harassment. Adolescents in carrying out their social roles should already know the rules and norms that apply in society. In line with that, adolescents should have better self-management in dealing with peers and their social environment. 
Based on this description, Sulandjari (2014) explains that it is necessary to have good self-awareness and self-management from themselves (adolescents), so that they are able to control their emotions and regulate themselves, not to behave rudely, talk dirty or behave aggressively. Charlton (2016) self-management is a term used to describe the process of achieving independence. The individual is a blend of intellectual, emotional, spiritual, and physical. So that self-management is self-control of thoughts, words, and actions that are carried out, and encourage oneself to do bad things and increase good and right actions.

Simbolon (2018) describes the condition of sexual abuse in the school environment that makes a person feel offended, humiliated and / or intimidated where a reaction like that is reasonable in the circumstances and conditions. The factors that influence the cause of sexual harassment are age, education, social relations with the environment, knowledge, and based on the preliminary survey as follows: clothing, technology, family, psychology, self-control, posture, culture, religion, and habits.

In line with that, B. Suyanto (2010) explains that sexual harassment is a form of sexual violence and a violation of decency that is carried out unilaterally and is not desired by the victim. condemned by all. Sexual harassment acts such as being whistled, teased with obscene words, poked or looked at in a way that seems to be naked which can cause feelings of irritability, humiliation and anger. Furthermore, Collier (1998) also explains that sexual harassment is behavior or attention of a sexual nature that is unwanted or unwanted and results in disturbing and harming the recipient of the harassment because of matters relating to sex, sexual activity between men and women.

Based on the opinions above, it can be concluded that the act of sexual harassment is a form of unwanted sexual activity in the form of humiliation or looking down on someone which is carried out unilaterally and is not desired by the victim where it is very detrimental to the victim both physically and psychologically. Various problems felt by students in schools BK teachers provide services that are in accordance with student behavior that occurs in schools. The provision of guidance and counseling services aims so that students can manifest themselves as independent, responsible, creative students and productive workers (Hadi et al., 2013)

Sari (2015) explained that guidance and counseling teachers/counselors have a responsibility to prevent teenagers from being sexually abused, teenagers can become victims or become perpetrators of sexual harassment. One way to prevent sexual harassment from happening is to provide students with an understanding and knowledge about positive attitudes towards sexuality through guidance and counseling services. Group guidance services were chosen because each individual can play an active role, assisting in helping the problems experienced by either the individual or each member of the group, so that students can be more active, group dynamics can work well. Efforts that can be done by BK teachers in this case of sexual 
harassment is to provide group guidance services. Through group guidance services, students will be free to express opinions, free to develop feelings, thoughts, perceptions, insights and attitudes that support behavior to control themselves, be considerate, and contribute suggestions to fellow group members (Maiseptian et al., 2017).

Group guidance se rvices can be held anywhere, indoors or outdoors, at school or outside school. Wherever this group guidance service is carried out, it must be ensured that group dynamics can develop as well as possible (Prayitno, 2012). BK students and teachers can determine the place where BK services will be carried out according to mutual agreement. Group guidance services, students will be free to express their opinions, are free to develop feelings, thoughts, perceptions, insights and attitudes that support behavior for self-control, tolerance, and contribute suggestions to fellow group members. By conducting group guidance can form a positive attitude or behavior. Positive attitudes formed in students will also lead to positive behavior, both of which can be created if students have positive perspectives, responses and assessments of other people or certain objects around them and the events they experience (Nengsih et al., 2015).

Through the implementation of this group guidance service, it is hoped that it can solve the problem of sexual harassment that occurs among adolescent students, especially in the Pinang City Vocational High School. The implementation of this group guidance service has been carried out by BK teachers but does not use special techniques where the researchers offer special techniques to improve student selfmanagement in sexual harassment at SMK Ki Hajar Dewantara, Kota Pinang, namely by providing group guidance using expressive art therapy.

Self management is a process of changing the "totality of self" in terms of intellectual, emotional, spiritual, and physical so that what we want is achieved. Students can recognize and understand themselves or their potential and make changes in various aspects of both intellectual, emotional, spiritual, and physical aspects towards a better direction, and manage them well and can find opportunities for themselves (Amaliasari \& Zulfiana, 2018).

The advantage of this expressive art therapy is that it can be a way to communicate experiences that are difficult to verbalize, such as physical or sexual abuse, trauma, grief, and complex emotional experiences. Art therapy is also widely used as a means of resolving emotional conflicts, increasing self-awareness, developing social skills, controlling behavior, solving problems, reducing anxiety, mobilizing reality, increasing self-esteem and various other psychological disorders (Malchiodi, 2003).

Charlton (2016) argues that there is a need for self-awareness and good selfmanagement from themselves (adolescents), so that they are able to control their emotions and regulate themselves, not to behave rudely, speak dirty or behave 
aggressively. Self management is a procedure by which individuals regulate their own behavior.

Isna Ni'matus Sholihah (2017) explains that art therapy is a therapeutic activity that uses a creative process and is a form of expressive therapy for clients/counselees. This creative process can use many approaches and interventions ranging from drawing, making objects, singing, playing music, dancing, playing plays and composing poetry. Rappaport (2009) explains that art therapy also includes visual arts, creative processes and psychotherapy to improve emotional, cognitive, physical and spiritual well-being.

Pies (2008) explains that expressive therapy is a form of therapy used in psychotherapy and counseling that aims to channel individual emotions and thoughts, reduce stress and conflict, through the media of drama, making pictures and music. In line with that Rogers (1993) also describes expressive arts therapy or expressive arts therapy is a psychological therapy that combines psychology and the creative process to encourage emotional growth and healing. Expressive arts therapy as the use of various arts such as movement, drawing, coloring, sculpting, music, writing, sound, and improvisation in conditions that are conducive to experiencing and expressing feelings as media objects in a therapeutic relationship.

Based on this explanation, it can be concluded that expressive therapy is a form of therapy that can be used by counselors to help clients express and communicate feelings, feelings, thoughts through media and activities related to artistic activities, dance, drama, poetry, and forms of play.

\section{Method}

This study uses quantitative methods. This type of research is a true experimental pretestposttest group design. The population in this study were students of SMK Ki Hajar Dewantara, Kota Pinang and the sample was taken using the proportional stratified random sampling technique because the sample was taken by strata based on grade level. The data collection technique used a Likert Scale model instrument, the data were analyzed using the Wilcoxon Signed Ranks Test and the Kolmogorov-Smirnov Two Independent Samples with the help of SPSS version 20.

\section{Results and Discussion}

The results of the research that has been carried out at the Ki Hajar Dewantara Vocational School, Pinang City. A total of 26 students in class X, XI were divided into 13 students in the experimental group and 13 in the control group.

Specifically, this study was to determine the effectiveness of group guidance services using expressive arts therapy in improving adolescent self-management in sexual harassment. The data obtained are the results of the pretest and posttest related to students' selfmanagement in sexual harassment. Descriptive data were carried out in each research group (control group and experimental group). In the following, the researchers present the results of research on the effectiveness of group guidance services using expressive arts therapy in improving self-management of adolescents committing sexual harassment. 
Students at the pretest control group were in the low category as many as 13 students. After being given group guidance services without special treatment there was a change where the posttest results were 4 students in the high category, 8 students were in the medium category and 1 student was in the high category. in the very low category.

Students at the pretest in the experimental group were in the low category as many as 6 students, in the very low category as many as 7 students, After being given the treatment there was a change which can be seen from the posttest results as many as 2 students in the very high category, 8 students were in the category high, 3 students are in the medium category.

Table 1. Pretest and Posttest Results of Experimental Group Self Management

\begin{tabular}{cccccc}
\hline \multirow{2}{*}{ Score } & \multirow{2}{*}{ Category } & \multicolumn{2}{c}{ Pretest } & \multicolumn{2}{c}{ Posttest } \\
\cline { 3 - 6 } & & F & \% & F & $\%$ \\
\hline$\geq 168$ & Very high & 0 & 0,00 & 2 & 15,38 \\
$136-167$ & High & 0 & 0,00 & 8 & 61,54 \\
$104-135$ & Moderate & 0 & 0,00 & 3 & 23,08 \\
$72-103$ & Low & 6 & 46,15 & 0 & 0,00 \\
$\leq 71$ & Very low & 7 & 53,85 & 0 & 0,00 \\
\hline & Quantity & 13 & 100 & 13 & 100 \\
\hline
\end{tabular}

Based on the table above, shows that 13 members of the experimental group who were involved in the calculations, experienced an increase in scores from the pretest and posttest or experienced changes after being given group guidance services using expressive art therapy. In the pretest there are 6 students who are included in the low category and 7 students are included in the very low category. After being given the posttest 2 students were in the very high category, 8 students were in the high category and 3 students were in the medium category.

Tabel 2. Pretest and Posttest Results of Control Group Self Management

\begin{tabular}{|c|c|c|c|c|c|}
\hline \multirow{2}{*}{ Score } & \multirow{2}{*}{ Category } & \multicolumn{2}{|c|}{ Pretest } & \multicolumn{2}{|c|}{ Posttest } \\
\hline & & $\mathbf{F}$ & $\%$ & F & $\%$ \\
\hline$\geq 168$ & Very high & 0 & 0.00 & 0 & 0.00 \\
\hline $136-167$ & High & 0 & 0.00 & 4 & 30.77 \\
\hline 104-135 & Moderate & 0 & 0.00 & 8 & 61.54 \\
\hline $72-103$ & Low & 13 & 100.00 & 1 & 7.69 \\
\hline$\leq 71$ & Very low & 0 & 0.00 & 0 & 0.00 \\
\hline \multicolumn{2}{|c|}{ Quantity } & 13 & 100 & 13 & 100 \\
\hline
\end{tabular}

Table 2 shows that 13 people in the control group who were involved in the calculation, experienced an increase in the average score from the pretest and posttest or experienced a change after being given group guidance services regarding student self-management without special treatment. In the pretest there were 13 students who were included in the low category, after being given the posttest 4 students were in the high category, 8 students were in the medium category and 1 student was in the low category. 


\section{Conclusions}

Based on the results obtained, it can be stated that in general group guidance services using expressive arts therapy can improve self-management of students' sexual harassment, while in particular there is an increase in the average pretest and posttest scores of the experimental group self-management. This happens because students actively follow group guidance using expressive art therapy, so it is necessary to provide group guidance services using expressive art therapy. In addition, there was also an increase in the average pretest score and the average posttest score for control group students, this happened because the information provided was interesting for students, so an effort was needed to implement group guidance services using expressive art therapy to improve self management. sexually harassed students and self-management of experimental group students who were given group guidance services using expressive art therapy the control group was given group guidance services on self-management without special treatment, this can be seen in the posttest the average score of the experimental group increased higher of the mean score of the control group.

Based on the above, it can be ignored in this study proves that group guidance services using expressive arts therapy can improve students' self-management in sexual harassment. Increasing the score of group guidance services using expressive arts therapy increases self-management higher than providing information about selfmanagement without special treatment. This is evident from the increase in scores obtained by the experimental group who were given group guidance services using expressive arts therapy, which was higher than the control group which was only given group guidance services on self-management without special treatment.

\section{References}

Amaliasari, R. D., \& Zulfiana, U. (2018). Hubungan antara Self Management dengan Perilaku Agresi pada Siswa SMA Cognicia Cognicia.

Amaliasari, R. D., \& Zulfiana, U. (2018). Hubungan antara self management dengan perilaku agresi pada siswa SMA Cognicia Cognicia.

Edelson, S. M. (1998). Self Management. In Tersedia [online]: www.autism.org/self-manage.html [02 Oktober 2012].

Charlton, C. . (2016). Effects of a self-management procedure using student feedback on staff members' use of praise in an out-of-school time program.

Hadi, M. F. Z., Yusuf, A. M., \& Syahniar. (2013). Pemahaman Konselor Sekolah tentang Tugas Perkembangan Siswa dan Layanan yang Diberikan. Konselor, 2(1), 43-52. https://doi.org/10.24036/0201321733-0-00

Isna Ni'matus Sholihah. (2017). Kajian teoritis penggunaan art therapy dalam pelaksanaan layanan bimbingan dan konseling di SMK Isna Ni ' matus Sholihah. 1st ASEAN School Counselor Conference on Innovation and Creativity in Counseling, 173-182. http://ibks.abkin.org 
Komnas Perempuan. (2019). Siaran Pers Catatan Tahunan Komnas Perempuan 2019.https://www.komnasperempuan.go.id/read-news-siaran-pers-catatan-tahunancatahu-komnas-perempuan-2019

Nengsih, N., Firman, F., \& Iswari, M. (2015). Pengaruh Layanan Bimbingan Kelompok Terhadap Perencanaan Arah Karier Siswa SMA Pembangunan Laboratorium Universitas Negeri Padang. Konselor, 4(3), 136. https://doi.org/10.24036/02015436466-000

Prayitno. (2004). Seri Layanan Konseling. FIP UNP.

Rusyidi, B., Bintari, A., \& Wibowo, H. (2019). Pengalaman Dan Pengetahuan Tentang Pelecehan Seksual: Studi Awal Di Kalangan Mahasiswa Perguruan Tinggi. Share : Social Work Journal, 9(1), 75. https://doi.org/10.24198/share.v9i1.21685

Sari, I. puspita. (2015). Pentingnya Pemahaman Kedudukan Dan Fungsi Bahasa Indonesia Sebagai Pemersatu Negara Kesatuan Republik Indonesia. 1(1), 234.

Simbolon, D. F. (2018). Kurangnya Pendidikan Reproduksi Dini Menjadi Faktor Penyebab Terjadinya Pelecehan Seksual Antar Anak. Soumatera Law Review, 1(1), 43. https://doi.org/10.22216/soumlaw.v1i1.3310

Sulandjari, R. (2014). Literasi Media Sebagai Pengantisipasi Pelecehan Seksual Pada Anak dan Remaja (Studi Kasus di Kelurahan Pudakpayung Kecamatan Banyumanik Kotamadia Semarang ). Majalah Ilmiah Inspiratif, 2. Jurnal.unpand.ac.id

Syahniar. (2017). Pelatihan dan Workshop Pendekatan dan Teknik Konseling Expressive Therapy bagi Guru BK SLTP/ MTs.N Kota Padang. Jurnal Konseling Dan Pendidikan, Vol, 5,164 .

Suyanto, D. B. (2010). Masalah Sosial Anak (1st ed.). Prenada Media Group.

Widyastuti, E. S. A. (2009). Personal Dan Sosial Yang Mempengaruhi Sikap Remaja Terhadap Hubungan Seks Pranikah. Jurnal Promosi Kesehatan Indonesia Vol. 4 / No. 2 / Agustus 2009, 4. https://media.neliti.com/media/publications/4919-ID-personal-dan-sosial-yangmempengaruhi-sikap-remaja-terhadap-hubungan-seks-pranik.pdf 